\title{
The Potential Ghost Tour in Bandung
}

\author{
Dini Rahmawati \\ Bandung, Indonesia \\ E-mail: rahmawatidini@yahoo.com
}

\begin{abstract}
Bandung has places which are believed to be haunted. Those places become spooky for their stories related to miserable death, accidents and myth. Gradually, they have drawn attention of people to visit memorizing miserable past events, but at night. This article explores how this potential ghost tour is produced, performed and consumed. As the lightest form of dark tourism, this tour provides different experience of entertainment since the operator tries to present real ghost to tourists by using their supernatural power. Ghost tour in Bandung involves occults as the attraction of the tour and this have arisen curiosity of people on the invisible creature which is believed to be exist.
\end{abstract}

\section{Key words - dark tourism; ghost tour}

\section{INTRODUCTION}

Dark tourism is still weird to hear and is not popular yet among Indonesian people, although unconsciously, this type of tourism has been conducted by a lot of people. Dark tourism is different from other types of tourism. While other tourism offers and presents excitement and happiness, dark tourism provides things related to human tragedy, disaster, death with violence and hecatomb.

There are variety of tourist objects related to death and human tragedy, such as war museums, monuments, battle field, prisons, refugee camps, disaster field, ghost tour, etc. People visit those places to get a flashback of the past and see the remains of tragic events. Some of them are Holocaust in Poland, Killing Field in Cambodia and Ground Zero in the United States. Indonesia has also all the resources related to dark tourism. It has not been fully identified because of the limitation of research on this subject. Some places related to dark tourism objects are Lubang Buaya in Jakarta, Galang Island in Riau Islands, Tsunami Museum in Aceh and Bali Bomb Monument in Bali.

As one of the lightest forms of dark tourism, ghost tour begins to draw attention of many people in Bandung, especially the young ones. The invisible creatures are believed to be exist and has led to curiosity of the real appearance among the people. The myth and human tragedy at sites are supporting in creating spooky atmosphere. In some countries like England, Spain and the United States, ghost tours have been managed as tour packages and offered by tour operators. Meanwhile, ghost tour in Bandung is operated by a community of young people who still consider it as a hobby and a routine activity.

\section{LITERATURE REVIEW}

Damanik (2012) identified dark tourism as memory tourism. It is because this tourism recalls the past events related to death and disaster. Thus, this makes it to be a miserable memory. His writing focuses on the typology of dark tourism. Without purposing to exploit the tragic history, in fact that people seem to like visiting places, where macabre events took place, with various motivations. Another researcher described dark tourism as visitation to sites related to death, suffering and seemingly macabre (Sharpley, 2009). His discussion leads to the theoretical perspective on dark tourism. He also cited from Bristow and Newman (2004) the term of fright tourism as a variation of dark tourism where individuals may seek a thrill or shock from the experience. The fright element of a tourism experience may not necessarily be death related.

Stone (2009a) explored constructed dungeons, The London Dungeon and The York Dungeon in England, which are considered as the lightest form of dark tourism. This form includes ghost tour which is part of dark fun factories (Stone, 2006) that focus on entertainment and commercial and present real and fictional death as well as macabre events. Garcia (2012) concluded that ghost tourism refers to the desire to encounter ghosts and interest in the supernatural, and visiting places associated with the spirit world such as cemeteries, haunted houses, castles and historic towns. She explored the interpretative, managerial and ethical issues of ghost tours in Edinburgh and Toledo. Thompson (2010) stated that ghost tour hinge on humanity's near fascination with the spirit world. He explored ghost tour in Gettysburg and on how the tour operator managed and performed the ghost tour to entertain tourists. Ghosts provide a metaphysical interpretation of real human tragedy and thus turn the experience of visitation of dark tourism sites into a "thrilling" experience (Garcia, 2012).

\section{METHOD}

Since the ghost tour in Bandung is still known as a new activity which is not completely a commercial tour like other tour packages, the ghost tour operator is approached to explore the following questions:

- How does the community, as the operator, run the tour?

- What are the main feature of the tour in terms of the tour content and the delivery method?

- How do the tourists consume the tour?

To find the answers of the questions, this study used qualitative method for the exploration like most of dark tourism research. The study employed participant observation and semi-structured interview on the data collection method to achieve the consistency of the findings. Participant observation was conducted to get actual data from the fields. It would be different from the non- 
participant observation where the writer wouldn't see the situation when the ghost tour was running. Semi-structured interview was carried out with tourists and the community in Bandung during the assembling of the tourists and the community every Wednesday night before the ghost tour was taken on Saturday. The interview was digitally recorded and then transcribed later on. The collecting data by these methods were conducted from February to May in 2015. The exploration of ghost tour was conducted at three places, Belanda Cave in Taman Hutan Raya Ir. H. Djuanda, Mount Sadu and Geology Museum.

Belanda Cave was chosen because this cave has macabre history. During the occupation of Dutch, this cave was a fort and a place where Dutch captivated Indonesians who fought for independence. The Dutch tortured and forced them to work until died. Therefore, this place comprises history and human tragedy. Moreover, there is a myth about "Lada" who is said to be a powerful person in the past. Mount Sadu was chosen for the myth there and Geology Museum for the history.

\section{GHOST TOUR IN BANDUNG}

Ghost tour in Bandung was begun by a group of young people who were curious of haunted places - sites allegedly inhabited by ghost, the undead or vampire (Harlingue, 2001). Previously, they talked about haunted places on Kaskus, a website on internet. Then they met each other for real and started to make a tour of haunted places based on the rumors spread in the society. Those places could be indoor sites like old buildings, museum and outdoor like waterfalls, mountains and forests. After a while, this activity spread and was recognized by many people (next will be called as tourists) and made them finally join the tour. Seeing this, the group of young people created a community called "Wisata Mistis" and has become the operator of ghost tour. Since then, there have been a lot of new destinations in Bandung and surroundings are revealed and become famous for their spooky stories and myths. Although this is a community's activity, however, they have a permission from the local authorities to do this tour. To decide which sites to visit, the community retrieves the information from different sources such as television, mass media, internet, rumors, members of the community and even tourists.

This community holds ghost tour twice a month on Saturday. They assemble on Wednesday night with the tourists who will join the tour for discussing the tour sites and giving the tourists information about the site and the rules during the tour. This assembling takes place on Jalan Ganesa, in front of the gate of Institut Teknologi Bandung. This ghost tour is actually not a commercial one because the community does not withdraw any fee from the tourists. They only have to pay for the parking, entrance ticket at the ghost tour sites and the tip for the local guide. Except for a special ghost tour request outside the tour schedule, the tourists will be charged for some fee approximately Rp. 85,000 (eighty five thousand rupiahs) per person. The tourists from outside Bandung will be given brief information by the community before the tour begins at the ghost tour site. The rules during the ghost tour are:
- The minimum age of tourist is 17 years old.

- The tourists must behave themselves in good manner, such as not to burst into laugh too loud, not to speak offhanded and rudely and keep the environment tidy.

- For the female tourists who are having period must report it to the metaphysic team since those are usually very easy to be possessed by ghosts, so they will be given kind of "shields" to protect them from ghosts.

- Tourists must not bring any things contain magical power otherwise they must entrust those things to the metaphysic team to prevent from any unexpected incident happen.

The entourage leaves for the ghost tour site by their own transportation, most of them by motorcycles, starts from Jalan Ganesha or from the place as they have agreed in discussion on Wednesday. At the ghost tour site, everybody assembles at the parking park and have a short briefing. The leader of the community must be sure that the tourists understand and follow the rules. The tourists, then, are divided into a few groups. Each group is led by two members of the community. This group division is meant to enable the community to take the tourists around the site easily and safely. In addition, the fewer tourists are taken around the site, the scarier the atmosphere is at night since silence and darkness are around them.

When ghost tour was carried out at Belanda Cave, there were 50 people including the community members going for the tour. The tourists were divided into 3 groups. Each group comprised 13 tourists and led by 2 members from the community. At Mount Sadu, tourists were divided into 2 groups with 10 tourists each group and led by 1 community member. There were around 30 people including the community members going for the tour at that time. While at Geology Museum, tourists were not divided into groups. The local guide wanted the tour was done altogether around the museum.

Ghost tour is started with walking and exploring around the site. While doing so, the local guide tells the history of the site. The tourists are allowed to ask the guide any questions about the site during the tour. The guide stops for a while at certain spots when giving explanation. Usually the light at the ghost tour site is poor, sometimes even dark, so it is necessary to bring a flashlight.

Ghost tour at Belanda Cave was begun at $11 \mathrm{pm}$. The tourists had to walk more less 1 kilometer from the parking lot to the cave in the middle of a conservation forest. After being divided into groups, the tourists started to walk around in the cave while holding flashlights. Other groups started walking after 5 minutes from the previous entered the cave. The guide told history while walking inside the cave. Sometimes the group stopped for a while at certain spot. The guide wore casual clothes and spoke clearly. Nothing was special or extraordinary with the guide because he was just like other guides explaining the site. Another 
person who also contributed as the guide was someone from metaphysic team - a team in the community comprises of a few people with supernatural power. As a person with supernatural power, he explained variety of ghosts that inhabited the site. This was verified by some tourists who also had the same power and even one of them made some drawings of ghosts he saw. Other "normal" tourists listen carefully and no one showed scary feeling while listening to the explanation. Sometimes some of them asked questions about both history of the cave and ghosts.

Ghost tour at Mount Sadu was different situation from the one at Belanda Cave. The groups climbed up the mountain at $5 \mathrm{pm}$ and then assembled on the top of the mountain while listening to the local guide explaining about the mountain and the myth. The local guide even brought a compass to give more detail information and proof that the mountain was full of magnetic stones. The tourists seemed to be fresh there because of the clean air and beautiful scenery from the high area.

Ghost tour at Geology Museum was started at $7.30 \mathrm{pm}$ and it was like other common tours in museum. The difference was that there were not any other tourists besides the ghost tour tourists. At night, lights were on all over the museum area and that provided different atmosphere from that in the afternoon. Some spots and certain rooms looked dark. Since there were a lot of valuable materials in the museum, the ghost tour didn't work like two former ghost tours.

The previous research on ghost tour written by Inglis and Holmes (2003) showed that some ghost tour operators in Edinburg hired people to perform and acted as famous ghosts to make the tour scary. It is similar to ghost tour in Gettysburg (Thompson, 2010) where actors played as ghosts and guides wore costumes to frighten tourists. However, since the tourists knew that they were fake, so the ghost tours were not so scary and even they became something entertaining and fun. This is in the contrary of ghost tour in Bandung which a guide doesn't wear any costume to frighten the tourists. The guide wears his casual daily clothes. No actors are hired. The spooky atmosphere emerges because of the silence, darkness and the story of the site visited. At the Dungeon in London, York, Edinburgh, Amsterdam and Hamburg, ghost tours show a display of horror history from a certain period in the past which was presented in various ways such as a live show completed with actors and other shows using special effect (Stone, 2009). These indoor ghost tours provide fear, uproar, yet fun. For example, the Dungeon in London and York present a display of prisoner persecutions as well as horrible and pathetic past events. This type of attraction is similar to a ghost house in Bandung which takes place indoor and presents horrific things. The difference is a ghost house presents various scary ghosts either using special effect or actors who act as ghosts, but have no relation with history and no education. Meanwhile, the Dungeon provides educative presentation since the horrific displays are based on the history of the past events.
Thompson (2010) described that ghost tour guides at Gettysburg inserted fiction in their stories to frighten tourists. They even used humor as entertainment side for tourists. Ghost tour guides in Bandung do not insert fictional stories in their tours. The guides are local people who live nearby ghost tour sites. Sometimes one of the community members becomes the ghost tour guide, but the stories told are true based on the history and myths. They also don't use humor in the tours. Even though, the metaphysic team tells about invisible ghosts, but those are usually validated by other tourists who also have supernatural power. So it is concluded that the existence of ghosts are true.

Next attraction is to perform paranormal activity. In this part, the metaphysic team is trying to present ghosts to tourists. There are 3 parts of attraction in paranormal activity:

- Uji nyali. A tourist stays alone at a very haunted spot at the site. In this session there is a huge possibility for the tourists to feel, hear or even see the ghosts. This opportunity is open for any tourists who want to meet ghosts. However, meeting ghosts is not an assurance, but at least they will feel the haunted atmosphere at the site.

- Buka tirai. The tourists meet the ghosts together with the others, so they are not alone at a certain spot. They may walk around or just sit down somewhere. This part of activity is less fear than uji nyali, because the tourists are notalone. However, being able to meet ghost is still not an absolute promise. It depends on how sensitive they are to the surrounding atmosphere.

- Mediumisasi. In this session, one of metaphysic team becomes the centre of the attraction. He invites and inserts spirit of a ghost into his body. By this way, he becomes a mediator for the tourists to communicate with the ghost. The tourists are allowed to ask any questions to the ghost inside the mediator as long as the questions relate to the ghost tour site. In this situation, the mediator's voice changes in accordance with the type of ghost inside him.

Uji nyali at Belanda Cave was conducted by 3 tourists. They were placed in 3 different dark haunted tunnels with a candle for 20 minutes. Before they were left alone, the metaphysic team raised their sensitivity using his supernatural power in order to meet, hear or feel, at least, the ghosts inhabited at that site. Meanwhile, the rest of tourists were offered to join buka tirai. All the tourists were placed at one tunnel and sat down on the ground. The metaphysic team also then raised the sensitivity of all the tourists and they stayed there for about 20 minutes in the dark. After these were done, all the tourists were asked about their experiences during uji nyali and buka tirai. One tourist of uji nyali said that he could see shadows which one of them looked like a tiger. He also heard a sound of trolley running on the rail. There was a track of rail inside the cave which a long time ago was used to run a trolley loaded by weapons when Dutch occupied. Some tourists of buka tirai said that there were shadows and heard loud sound like something huge was slamming a few times from a distance. 
In fact that there isn't such huge thing can be slammed at the cave. However, it can't be denied that some tourists didn't feel anything, just silence and dark. Everybody had different level of sensitivity, so they also had different experiences during ghost tour. Next, the tour was continued to do mediumisasi. In this session, one of metaphysic team inserted a spirit of ghost into his body so that tourists were able to communicate with it. The mediator's voice changed into an old man's voice. The tourists then asked some questions related to the site and the ghost answered through the mediator. The tourists were also trying to prove whether the myth spreading at the site was true. It was said that if anyone said "Lada" then that person would be disturbed by ghosts, unfortunate and even possessed. Some tourists spoke "Lada" loudly and it was proved that nothing happened after that. The ghost didn't know anything about "Lada" either when he was asked about it.

Ghost tour at Mount Sadu was a bit more frightened. The tour could not be continued well. When paranormal activity, mediumisasi, was about to be carried out, suddenly evil ghosts attacked all members of the metaphysic team. The worst part, the writer was attacked by those ghosts as well. Because of this chaos, the community stopped the tour. So far, Mount Sadu has not been heard as a haunted place. According to the myth there is a sacred tomb on the top of the mountain and that is the reason why people visit it. But when the tour groups searched it through the keeper, who was also as the local guide, he said that there wasn't any sacred tomb there, only magnetic stones which gave good effect to the body.

Ghost tour at Geology Museum was far different from the others. The limitation of night visit didn't provide enough time to do any other activity in the tour. The tour began at $7.30 \mathrm{pm}$ and ended at $9.00 \mathrm{pm}$. Besides that, it was prohibited to do any paranormal activity in the museum. It was prevention from any unexpected things that would impact the valuable assets of the museum. However, the metaphysic team still did their part, to see and find ghosts inhabited there but they did not give detail explanation.

Ghost tour in Bandung doesn't promise the tourists to meet ghosts, but the community presents ghosts for them so that they obtain supernatural experience. Those who are very lucky are able to meet and see ghosts, the others are able to see the shadows of ghosts and hear voices like screaming and laughing after the metaphysic team sensitizes them by using supernatural power. Meanwhile, ghost tours in Edinburg and Gettysburg promise the tourists to meet ghosts (Garcia, 2012; Thompson, 2008; Thompson, 2010). However, none of tourists testified to have met ghosts. The ghosts who appeared were actors acted as ghosts and performed frightening performance.

TABLE I. Ghost tour attraction spectrum, adapted from Stone (2006)

\begin{tabular}{|ll|l|l|l|}
\hline Darkest & Dark & Dark/light & Light & Lightest \\
Uji Nyali & $\begin{array}{l}\text { Buka } \\
\text { Tirai }\end{array}$ & Mediumisasi & $\begin{array}{l}\text { Myth } \\
\text { Search }\end{array}$ & $\begin{array}{l}\text { History } \\
\text { Search }\end{array}$ \\
\hline
\end{tabular}

Based on the attraction of the ghost tour, spectrum adapted from Stone (2006) is made according to the level of eeriness from the darkest to the lightest. The darkest means the most fearful and the lightest means fearless attraction. First, uji nyali is placed in the darkest spectrum because the tourist is facing ghosts alone at the most haunted spot. Most of tourists consider uji nyali is the most frightening attraction. It is shown that only 3 tourists are willing to experience it. Second, buka tirai is placed in dark spectrum because tourists are not alone in facing ghosts but altogether with others. This attraction has less fear than uji nyali. Third, mediumisasi is placed in dark/light spectrum because tourists are able to communicate with ghosts through a mediator, so fear is less than the previous. Fourth, myth search is placed in light spectrum because the tourists only listen to the myth story while walking around the ghost tour site and without any attraction of meeting or feeling ghosts' existence. Fifth, history search is placed in the lightest spectrum because the tourists only listen to the history of the site from a guide.

\section{CONCLUSION AND SUGGESTION}

The community runs the tour by involving tourists, starts from selecting tour location, time, until tour performance such as giving the tourists opportunity to share and draw which ghosts they can see, to take part in uji nyali, buka tirai and mediumisasi so that they are able to see or hear or feel and communicate with ghosts at the ghost tour site. In addition, the tourists get knowledge about history of the site. Most of the tour content deals with supernatural power so that the metaphysic team performs in the tour like in myth search, uji nyali, buka tirai and mediumisasi, while history search is held by either local guide or guide in the community. Guides in ghost tours are just like other common tour guides. They give information to tourists about the site visited while walking around the ghost tour sites. They do not wear special costumes like ghost tour guides in England and the United States. They also do not mix any fictional story to frighten tourists in their explanation while guiding. All tourists follow the steps and the rules of the ghost tour so that the tour runs smoothly. They also involve in the ghost tour performance.

Ghost tour provides different experience from other tourism such as culinary, nature and shopping tourism. Haunted places have become the pull factor because they have drawn people to visit and curiosity has become the push factor that has made people come to those sites. Therefore, this activity is potential to be developed as a tour package because there are always people, outside the community member, who join the ghost tour either from Bandung or outside the city. It is expected that ghost tour is able to vary and to activate more tourism activity in Bandung.

Cultures from different countries may influence types of ghost tour. That is the reason why ghost tours are different from one another. Ghost tour in Bandung provides educative side and entertainment but doesn't contain humors. The scary atmosphere is not taken place by actors and special effect in order to make tourists frighten. This tour also gives 
a lesson how we as human being have to appreciate each other including environment, past history and even the invisibles.

The concept of this type of ghost tour sites is accidental or non-purposeful sites, which mean that they become attractions because of their relationship with tragic events (Stone, 2006). Those ghost tour sites are actually common attractions where tourists visit during the day. Yet, due to the myth stories, along with history, those places have drawn people's attention to come for ghost tour. Not a single thing is the sites constructed for ghost tour. Haunted atmosphere emerges as the night is getting late and more and more silent, not to mention spooky stories are told by the guides.

The community, indirectly, becomes a mean for people who have sixth sense and supernatural power to meet one another. Meanwhile, metaphysic team is an important team in the community because they have a role to perform attractions and to secure the tour from any disturbance of the supernatural.

It is advisable that the tour is planned and managed professionally in order to be more attractive and frightening so that this tour can be sold at tour and travel agent as a tour package. Ghost tour with experience which raises adrenaline may be unforgettable and impressive to tourists. Promotion is also necessary to draw attention of more tourists. For example put a promotion on mass media, radio or participate at any tourism exhibition. The community should announce ghost tour to the department of tourism and creative economic about its existence in order to obtain recognition that this tour has participated to enliven tourism in Bandung.

\section{REFERENCES}

[1] J. Damanik, Tipologi Dark Tourism, Jakarta: Kementrian Pariwisata dan Ekonomi Kreatif, 2012.

[2] B. A. D'Harlingue, Haunted Tourism: Sites of Violence and Memory in the United States, Dissertation: University of California Santa Cruz, 2001.

[3] B.R. Garcia, "Management issues in dark tourism attraction: the case of ghost tours in Edinburgh and Toledo," Journal of Unconventional Parks, Tourism \& Recreation Research, Vol. 4, 2012, pp. 14-19.

[4] D. Inglis, and M. Holmes, "Highland and other haunts: ghosts in Scottish tourism," Annals of Tourism Research, Vol. 30, No. 1, 2003, pp. 50-63.

[5] R. Sharpley, "Shedding Light on Dark Tourism: An Introduction," in R. Sharpley and P. Stone (ed): The Darker Side of Travel: The Theory and Practice of Dark Tourism, Bristol: Channel View Publications, 2009, pp. 3-22.

[6] P.R. Stone, "A dark tourism spectrum: towards a typology death and macabre related tourist sites, attractions and exhibition," An Interdisciplinary International Journal, Vol. 54, No. 2, 2006, pp. 145160.

[7] P.R. Stone, "It's a bloody guide: fun, fear and a lighter side of dark tourism at The Dungeon visitor attractions, UK," in R. Sharpley and P. Stone (ed): The Darker Side of Travel: The Theory and Practice of Dark Tourism, Bristol: Channel View Publications, 2009a, pp. 167185.

[8] R.C. Thompson, Entertaining Ghosts: Gettysburg Ghost Tours and the Performance of Belief, Thesis: The Graduate School of the University of Maryland, 2008.

[9] R.C. Thompson, "Am I going to see a ghost tonight? : Gettysburg ghost tours and the performance of belief," The Journal of American Culture, Vol. 33, 2010, pp. 79-91. 